\title{
Effects of Burnable Absorbers on PWR Spent Nuclear Fuel
}

P. M. O'Leary, Framatome Cogema Fuels

Dr. M. L. Pitts. Framatome Cogema Fuels

3315 Old Forest Rd. Lynchburg. VA 24506

(804) 832-2838 (w) (808) 832-2932 (Fax)

\section{INTRODUCTION}

Burnup credit is an ongoing issue in designing and licensing transportation and storage casks for spent nuclear fuel (SNF). To address this issue, in July 1999, the U.S. Nuclear Regulatory Commission (NRC), Spent Fuel Project Office, issued Interim Staff Guidance-8 (ISG-8), Revision $1^{1}$ allowing limited burnup credit for pressurized water reactor (PWR) spent nuclear fuel (SNF) to be used in transport and storage casks. However, one of the key limitations for a licensing basis analysis as stipulated in ISG-8, Revision 1 is that "burnup credit is restricted to intact fuel assemblies that have not used burnable absorbers." Because many PWR fuel designs have incorporated burnable-absorber rods for more than twenty years, this restriction places an unnecessary burden on the commercial nuclear power industry. This paper summarizes the effects of in-reactor irradiation on the isotopic inventory of PWR fuels containing different types of integral burnable absorbers (BAs). The work presented is illustrative and intended to represent typical magnitudes of the reactivity effects from depleting PWR fuel with different types of burnable absorbers.

\section{DESCRIPTION}

Two general types of burnable absorbers (BAs) are used with PWR fuels ${ }^{2}$ : integral burnable absorbers and burnable poison rods (BPRs). Integral burnable absorbers (IBAs) are nonremovable, neutron-absorbing materials used as components of a fuel assembly. BPRs, however, are rods that contain neutron-absorbing materials that can be inserted in PWR assembly guide tubes. Both types of BAs can be used to control reactivity and local power peaking and optimize fuel utilization. In general, both types of BAs are designed to function during the first cycle of irradiation of a fresh, unirradiated fuel assembly. After one cycle of irradiation, the BPRs are typically removed from the fuel assembly allowing primary coolant to occupy the guide tube volume displaced from the BPRs. In the case of IBAs, the rods remain in the fuel assembly throughout its lifetime and usually account for a small reactivity penalty at end of life, due to incomplete consumption of the neutron-absorber material

PWR fuels use several different types of integral burnable absorbers. For example, in some IBAs, neutron absorbers such as gadolinia $\left(\mathrm{Gd}_{2} \mathrm{O}_{3}\right)$ and erbia $\left(\mathrm{Er}_{2} \mathrm{O}_{3}\right)$ are mixed directly with the uranium dioxide $\left(\mathrm{UO}_{2}\right)$ fuel in select rod locations withın an assembly. The Westinghousedesigned Integral Fuel Boron Absorber (IFBA) rods contain uranium pellets with a thin coating of zirconium diboride $\left(\mathrm{ZrB}_{2}\right)$. Other integral absorbers, such as boron carbide $\left(\mathrm{B}_{4} \mathrm{C}\right)$, are mixed in alumina $\left(\mathrm{Al}_{2} \mathrm{O}_{3}\right)$ pellets placed in rods that replace uranium fuel rods in some Combustion Engineering-designed fuel assemblies.

There are also several general types of BPRs that have been used in PWR fuels. Framatome Cogema Fuels (FCF) uses BPRs composed of $\mathrm{Al}_{2} \mathrm{O}_{3}-\mathrm{B}_{4} \mathrm{C}$ pellets contained in zircaloy tubing. The Westinghouse configuration for BPRs uses hollow Pyrex glass $\left(\mathrm{B}_{2} \mathrm{O}_{3}-\mathrm{SiO}_{2}\right)$ tubing sealed in stainless steel cladding. More recently, Westinghouse has used wet annular burnable 
absorbers (WABAs) that are similar to the Pyrex absorbers but use hollow $\mathrm{Al}_{2} \mathrm{O}_{3}-\mathrm{B}_{4} \mathrm{C}$ pellets clad in zircaloy with a central water region for enhanced neutron moderation.

PWR fuels containing typical loadings of gadolinia, erbia, and boron coated uranium fuel pellets have been analyzed to investigate their neutronic effects on PWR SNF. In addition, PWR fuels containing Pyrex and WABA BPRs have been analyzed to investigate their neutronic effects on PWR SNF. Plots of these results will show the reactivity difference of "poisoned" and "unpoisoned" fuel with the same initial enrichment as a function of burnup. Each infinite-array lattice, poisoned and unpoisoned. was depleted with CASMO- $3^{3}$ under normal hot operating conditions. Three cycles of $15 \mathrm{GWd} / \mathrm{MTU}$ exposure each were used to represent the depletion history effects on the fuel. Restart calculations were then run at each burnup point removing the Xenon, setting the soluble boron to $0 \mathrm{ppmB}$, and the fuel and moderator temperatures to $300 \mathrm{~K}$ to simulate storage cask conditions. For the BPR cases analyzed, the BPRs were removed from the fuel after one and two cycles of depletion. After removal, the BPRs were replaced with water and depleted to end of life conditions. To evaluate their effect on fuel assembly isotopic inventory, the BPRs were not included in the restart calculations. No decay periods were accounted for in the analyses. However, isotopic decay will be considered at a later date for disposal purposes.

\section{RESULTS}

The results indicate that the reactivity effect from burnable absorbers on PWR SNF is generally small and well behaved (smoothly varying as a function of fuel burnup) and can be well characterized. For gadolinia. the k-infinity for gadolinia-bearing fuel is always less than that for the non-gadolinia fuel. The difference is approximately $0.1-0.2 \%$ delta-k near 45 GWd/MTU For erbia, the k-infinity for erbia-bearing fuel is also always less than that for the non-erbia fuel The difference is approximately $1 \%$ delta-k near $45 \mathrm{GWd} / \mathrm{MTU}$ For IFBAs, the k-infinity for IFBA-bearing fuel became greater than that for the non-IFBA fuel by approximately $0.18 \%$ delta-k near $35 \mathrm{GWd} / \mathrm{MTU}$ where it began to decrease with further burnup. For Pyrex BPRs. the effect on $k$-infinity is greater than that for the non-BPR fuel, by approximately $2 \%$ delta-k at the time of removal and diminishes slightly with further irradiation. For WABA BPRs, the effect on $k$-infinity is greater than that for the non-WABA BPR fuel, by less than $1 \%$ delta-k at the time of removal and diminishes slightly with further irradiation.

Given these results. consideration should be given to removing the restriction on burnup credit for PWR fuel assemblies that have used burnable absorbers.

\section{REFERENCES}

1. U. S. Nuclear Regulatory Commission, Spent Fuel Project Office Interim Staff Guidance - 8 . Revision 1. Washington D. C., July 30, 1999

2. Characteristics of Potential Repository Wastes DOE/RW-0184-R1. Volume 1. December 1987.

3. CASMO-3, A Fuel Assembly Burnup Program, Version 4.8. Studsvik/NFA-89/3. November 1996 